\title{
MOLECULAR CLONING, FUNCTIONAL EXPRESSION AND CHROMOSOMAL LOCALIZATION OF THE HUMAN CHOLECYSTOKININ TYPE A RECEPTOR+
}

\author{
Andreas de Weerth ${ }^{1}$, Joseph R. Pisegna ${ }^{1}$, Konrad Huppi², and Stephen A. Wank1,3
}

\begin{abstract}
1Digestive Diseases Branch, National Institute of Diabetes and Digestive and Kidney Diseases, and the 2Laboratory of Genetics, Molecular Genetics Section, National Cancer Institute, National Institutes of Health, Bethesda, Maryland
\end{abstract}

Received June 14, 1993

The cholecystokinin (CCK) family of peptides and receptors are present throughout the brain and gastrointestinal tract and can be pharmacologically subdivided into two subtypes: $\mathrm{CCK}_{\mathrm{A}}$ and $\mathrm{CCK}_{\mathrm{B}}$. Little is known about the localization, pharmacology and function of $\mathrm{CCK}_{\mathrm{A}}$ receptors $\left(\mathrm{CCK}_{\mathrm{A}} \mathrm{R}\right)$ in humans. We used the rat $\mathrm{CCK}_{\mathrm{A}} \mathrm{R}$ CDNA to isolate the human CCK receptor CDNA homologue from human gallbladder which encodes a unique 428 amino acid protein having $>90 \%$ homology to the rat and guinea pig $\mathrm{CCK}_{\mathrm{A}} \mathrm{R}$. Expression of the recombinant $\mathrm{CCK}_{\mathrm{A}} \mathrm{R}$ in COS-7 cells displayed a pharmacological profile characteristic of a $C C K_{A} R$ subtype and mediated agonist stimulated increase in total inositol phosphates. Northern hybridization identified a transcript measuring $6 \mathrm{~Kb}$. The human $\mathrm{CCK}_{A} \mathrm{R}$ gene maps to chromosome 4. These results describe for the first time the molecular cloning, expression and chromosomal localization of the human $\mathbf{C C K}_{\mathrm{A}}$ receptor. 1993 Academic Eress, Inc.

The cholecystokinin (CCK) family of peptides occurs throughout the gastrointestinal, central (CNS) and peripheral nervous systems $(1,2)$. Receptors for CCK can be biologically and pharmacologically classified on the basis of their relative affinity for nonsulfated CCK analogues and selective antagonists into two subtypes, $\mathrm{CCK}_{\mathrm{A}}$ and $\mathrm{CCK}_{\mathrm{B}}$. The $\mathrm{CCK}_{\mathrm{A}}$ receptor $\left(\mathrm{CCK} \mathrm{A}_{\mathrm{A}} \mathrm{R}\right)$ subtype has high affinity only for sulfated analogues of CCK and the antagonist, L-364,718, while the CCK $B$ receptor subtype has nearly equal affinity for sulfated and nonsulfated analogues of CCK and the antagonist, L365,260 (2,3).

Both subtypes are guanine nucleotide-binding regulatory protein-coupled receptors capable of activating phospholipase $\mathrm{C}$ and stimulating an increase in diacylglycerol, inositol phosophates and the subsequent release of intracelluar calcium $(4,5,6)$.

$\mathrm{CCK}_{\mathrm{A}} \mathrm{Rs}$ have diverse physiologic roles in the gastrointestinal system where they mediate pancreatic growth and enzyme secretion, smooth muscle contraction of the gallbladder and stomach and secretion from gastric mucosal cells (2). In humans meal-induced gallbladder contraction and fasting tone are mediated by CCK $(7,8)$. Abnormalities in gallbladder contraction to exogenously administered CCK have been observed in patients with irritable bowel syndrome, suggesting a generalized abnormality of smooth muscle function and possibly altered $\operatorname{CCK}_{\mathrm{A}} \mathrm{R}$ function in this

\footnotetext{
+ Sequence data from this article have been deposited in the Genbank data base (accession no. L19315)

${ }^{3}$ To whom correspondence should be addressed.
} 
subgroup of patients (9). CCK may have a role in the control of postprandial hyperglycemia and abnormalities in CCK secretion after meals may contribute to the hyperglycemia observed in noninsulin-dependant diabetes mellitus (10). $\mathrm{CCK}_{\mathrm{A}}$ Rs have also been shown to be expressed on human pancreatic and colon cancers, and in gastric smooth muscle tumors, including leiomyomas and leiomyosarcomas $(11,12,13)$. The growth of some human pancreatic cancer cell lines has been shown to be stimulated by $\mathrm{CCK}$ (14). The selective $\mathrm{CCK}_{\mathrm{A}} \mathrm{R}$ antagonist devazepide $(\mathrm{L}-364,718)$ has been shown to inhibit the growth of a human pancreatic cancer cell line SW-1990 (14).

In the nervous system of aniamls, $\mathrm{CCK}_{\mathrm{A}} \mathrm{Rs}$ are present in select areas such as the anterior pituitary, where they regulate $\beta$-endorphin release, mesolimbic neurons, where they regulate dopamine release, and in the nucleus tractus solitarius, area postrema and hypothalamus, where they regulate satiety $(15,16)$. Peripheral nerves, such as the vagus, also contain $C_{C K} K_{A}$ s that regulate satiety, gastric motility and acid secretion and pancreatic secretion (16). Autoradiographic studies of human brain using 125I-BH-CCK-8 have not been routinely performed because of the difficulty in obtaining fresh human brain tissue. In human brain, CCK-immunoreactive neurons have been identified in the supragranular layers of the cerebral cortex suggesting its role as a neurotransmitter (17). Furthermore, CCK-containing dopaminergic neurons have been implicated in the pathogenesis of schizophrenia, Parkinson's disease, drug addiction, and feeding disorders (15).

Little is known about the structure, pharmacology and cell biology of human $\mathrm{CCK}_{\mathrm{A}} \mathrm{Rs}$ because of the difficulty in obtaining fresh human tissue or long term cultures in normal tissues expressing the $\mathrm{CCK}_{\mathrm{A}} \mathrm{R}$. Human gallbladders in patients undergoing cholecystectomy have been shown to possess a single $\mathrm{CCK}_{\mathrm{A}}$ binding site that is functionally and biochemically intact in diseased specimens (18), therefore, we elected to PCR clone the human $C_{C K} R$ cDNA from a surgical gallbladder specimen using $5^{\prime}$ and $3^{\prime}$ noncoding sequence obtained from screening a human genomic library with the recently cloned rat $\mathrm{CCK}_{\mathrm{A}} \mathrm{R}$ cDNA (19).

\section{MATERIALS AND METHODS}

TISSUE PROCUREMENT, RNA ISOLATION, and cDNA SYNTHESIS: Human gallbladder was obtained as a fresh surgical specimen and immediately frozen in liquid nitrogen. Total RNA was isolated using a low temperature guanidine isothiocyanate method (20) and poly (A)+ RNA was isolated using oligo $d(T)$ cellulose chromatography. Oligo $d(T)$ primed cDNA was synthesized using Superscript reverse transcriptase (BRL, Gaithersburg, MD) from one microgram poly (A)+ RNA.

ISOLATION OF CDNA CLONES: A human placenta genomic library in Lambda FIX II vector (Stratagene, LaJolla, CA) was screened using a [32P] random primed probe derived from the rat $\mathrm{CCK}_{\mathrm{A}}$ receptor cDNA(19). Approximately $7.5 \times 10^{5}$ clones were screened at low stringency $\left(3 \times 20^{\prime}\right.$ washes at $370 \mathrm{C}, 2 \mathrm{X}$ SSC/0.1\% SDS [1X SSC $=.15 \mathrm{M} \mathrm{NaCl} ; 15 \mathrm{mM}$ sodium citrate). Positively hybridizing clones were plaque purified.

PCR CLONING: To obtain a full length human $\mathrm{CCK}_{\mathrm{A}}$ receptor $\mathrm{CDNA}$, approximately $5 \mathrm{ng}$ of single stranded human gallbladder cDNA and the following primers were used in the polymerase chain reaction. The 5' sense primer, 5'-GGCAGG'TTGCATCTGCGAGAC-3' (nucleotides 54 to 73, Fig. 1) and the 3 ' antisense primer: 5'-CGTTCTTTCTTCTCTGCCTCC-3' (complementary nucleotides 1500 to 1480 , Fig. 1) were derived from the $5^{\prime}$ and $3^{\prime}$ noncoding regions of the clone isolated from the human placenta genomic library described above. Each primer contained an additional $5^{\prime} 9$ bp cap and Xba I site (GACTAGCCGGAATTC) necessary for subsequent ligation into the vector, pCDLSR $\alpha$ at the Eco RI restriction enzyme site.

DNA SEQUENCING: Both strands of the cDNA clones isolated from the human placenta genomic library and the product from PCR cloning from the human gallbladder cDNA were sequenced using the dsDNA Cycle Sequencing System (Bethesda Research Laboratory, Gaithersburg, MD).

DNA AND PROTEIN SEQUENCE ANALYSIS: The nucleotide and deduced amino acid sequences were analyzed by the Wisconsin Genetics Computer Group software package using the "Pileup" program (21).

NORTHERN BLOT ANALYSIS OF mRNAs: Approximately $2 \mu \mathrm{g}$ of poly (A)+ RNA isolated by oligo d(T ) cellulose chromatography were loaded in each lane and were separated electrophoretically on a $1.5 \%$ agarose/formaldehyde denaturing gel and blotted onto Nytran (Schleicher and Schuell, 
Keene, NH). The blot was hybridized with a $[32 \mathrm{P}]$ random prime labelled probe derived from the coding region of the human $\mathrm{CCK}_{\mathrm{A}}$ receptor $\mathrm{CDNA}$, at $37^{\circ} \mathrm{C}$ overnight as described $(22)$ and washed at low stringency $\left(3 \times 20^{\circ}\right.$ washes with $2.0 \times$ SSC $/ 0.1 \%$ SDS @ $\left.37^{\circ} \mathrm{C}\right)$ and then high stringency $(3 \times$ $20^{\prime}$ washes with $0.1 \times$ SSC $/ 0.1 \%$ SDS @ $42^{\circ} \mathrm{C}$ ). The blot was exposed for 48 hours and processed using a phosphorimager (Molecular Dynamics) following each of the low and high stringency washes.

SOUTHERN BLOT ANALYSIS OF HUMAN GENOMIC DNA: Ten ug of human genomic DNA was digested with either Eco RI or Xba I, separated electrophoretically on a $1.0 \%$ agarose gel and blotted onto Nytran (Schleicher and Schuell, Keene, NH). The blot was hybridized with a [32P] random prime labelled probe derived from the coding region of the human $\mathrm{CCK}_{\mathrm{A}}$ receptor cDNA, at $37^{\circ} \mathrm{C}$ overnight as described (22) and washed at low $\left(3 \times 20^{\prime}\right.$ washes with $2.0 \times \mathrm{XSC} / 0.1 \%$ SDS @ $37^{\circ}$ C) and then high stringency $\left(3 \times 20^{\prime}\right.$ washes with $0.1 \times$ SSC $/ 0.1 \%$ SDS @ $\left.42^{\circ} \mathrm{C}\right)$. The blot was exposed for 48 hours and processed using a phosphorimager (Molecular Dynamics) following each of the low and high stringency washes.

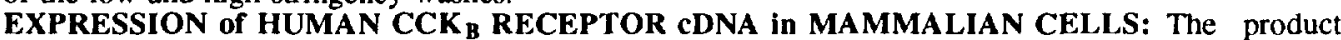
cloned by PCR amplification from human gallbladder cDNA described above was digested with Xba $I$ and ligated into the vector $\mathrm{pCDL}-\mathrm{SR} \alpha(23)$ at the $\mathrm{Xba} I$ site in the sense orientation. Two micrograms of vector plus insert were transfected into COS-7 cells $\left(\approx 1 \times 10^{6}\right.$ cells per $100 \mathrm{~mm}$ tissue culture plate) using the DEAE/dextran method as described (24). Approximately 48 hours after transfection, the cells were washed in phosphate buffered saline (PBS; pH 7.4) containing bovine serum albumin (BSA) $1 \mathrm{mg} / \mathrm{ml}$ at $4^{\circ} \mathrm{C}$, scraped from the culture plate and suspended in Dulbecco's Modified Eagle Medium (DMEM) containing BSA $1 \mathrm{mg} / \mathrm{ml}$, centrifiged (400X $\mathrm{g}$ ), and suspended in the same medium at $4^{\circ} \mathrm{C}(\approx 300,000 \mathrm{cells} / \mathrm{ml})$. Suspended cells $(500 \mu \mathrm{l})$ were incubated for 60 minutes at $370 \mathrm{C}$ with $50 \mathrm{pM}$ of $[125$ I]Bolton-Hunter-CCK-8 $(2200 \mathrm{Ci} / \mathrm{mmol})$ either with or without the indicated concentrations of unlabelled agonist or antagonist. Cells were subsequently washed three times at $40 \mathrm{C}$ with $2 \mathrm{ml}$ PBS containing BSA $1 \mathrm{mg} / \mathrm{ml}$ at $4{ }^{\circ} \mathrm{C}$ and filtered on glass fibers filters (Whatman GF/A) using a suction manifold (Millipore, Bedford, MA). The filters were subsequently assayed for gamma radioactivity (Packard, Auto-Gamma).

MEASUREMENT OF PHOSPHOINOSTIDES: Cells were trypsinized from $100 \mathrm{~mm}$ plates $24 \mathrm{hr}$ post transfection and replated in 24 -well plates in $9 \mu \mathrm{Ci} / \mathrm{ml}$ myo- $\left[2-{ }^{3} \mathrm{H}\right]$ inositol in Dulbecco's modified essential medium with $2 \%$ fetal bovine serum at $37 \circ \mathrm{C}$ for $24 \mathrm{hr}$. Total phosphoinositides in transfected COS-7 cells were determined as described previoulsy (25) following a 60 minute incubation at $37 \circ \mathrm{C}$ in the presence and absence of the indicated concentrations of agonist and antagonist.

CHROMOSOMAL MAPPING: Human chromosomal localization was performed using a somatic cell hybrid panel of human-hamster DNAs (BIOS Laboratories, New Haven, CT). A PCR assay using human $\mathrm{CCK}_{\mathrm{A}}$ receptor sequence specific sense, 5'-GAACAAACGCTTCCGCCTCGG-3' (nucleotides 1272 to 1292, Fig. 1), and antisense, 5'-CGTTCTTTCTTCTCTGCCTCC-3', (complementary nucleotides 1500 to 1480 , Fig. 1) primers with $50 \mathrm{ng}$ of genomic DNA was performed using standard protocols recommended by the manufacturer (Cetus Corp. Norwalk, CT).

\section{RESULTS AND DISCUSSION}

Screening approximately $7.5 \times 10^{5} \mathrm{cDNA}$ clones from a human placenta genomic library resulted in the isolation of 9 clones that hybridized under low stringency to the rat $\mathrm{CCK}_{\mathrm{A}}$ receptor probe (19). Partial sequencing at the 5 ' and $3^{\prime}$ ends of two full length clones indicated the presence of at least two introns. Therefore, the remaining sequence was obtained by PCR cloning from human gallbladder cDNA using sense and antisense primers derived from the 5 ' and 3 ' noncoding sequence obtained from genomic clones isolated from the human placenta library. This resulted in a $1686 \mathrm{bp}$ product (Fig. 1) with a single long open reading frame having $90 \%$ nucleotide homology with the rat $\mathrm{CCK}_{\mathrm{A}}$ receptor cDNA coding sequence. This high degree of homology is in the range expected for species-dependent polymorphisms within the same gene (26).

The 1284 bp single long open reading frame encodes for a unique 428 amino acid protein with a calculated molecular mass of $\approx 48 \mathrm{kDa}$ that is similar in size to the $43 \mathrm{kDa}$ deglycosylated core protein previously reported for the human gallbladder $\mathrm{CCK}_{\mathrm{A}}$ receptor using affinity crosslinking methods (27). A hydropathy plot (data not shown) using the criteria of Kyte and Doolittle (28) and homology with the rat and guinea pig $\operatorname{CCK}_{A}$ receptor $(19,29)$ identifies seven regions of hydrophobic residues corresponding to putative transmembrane domains expected for 


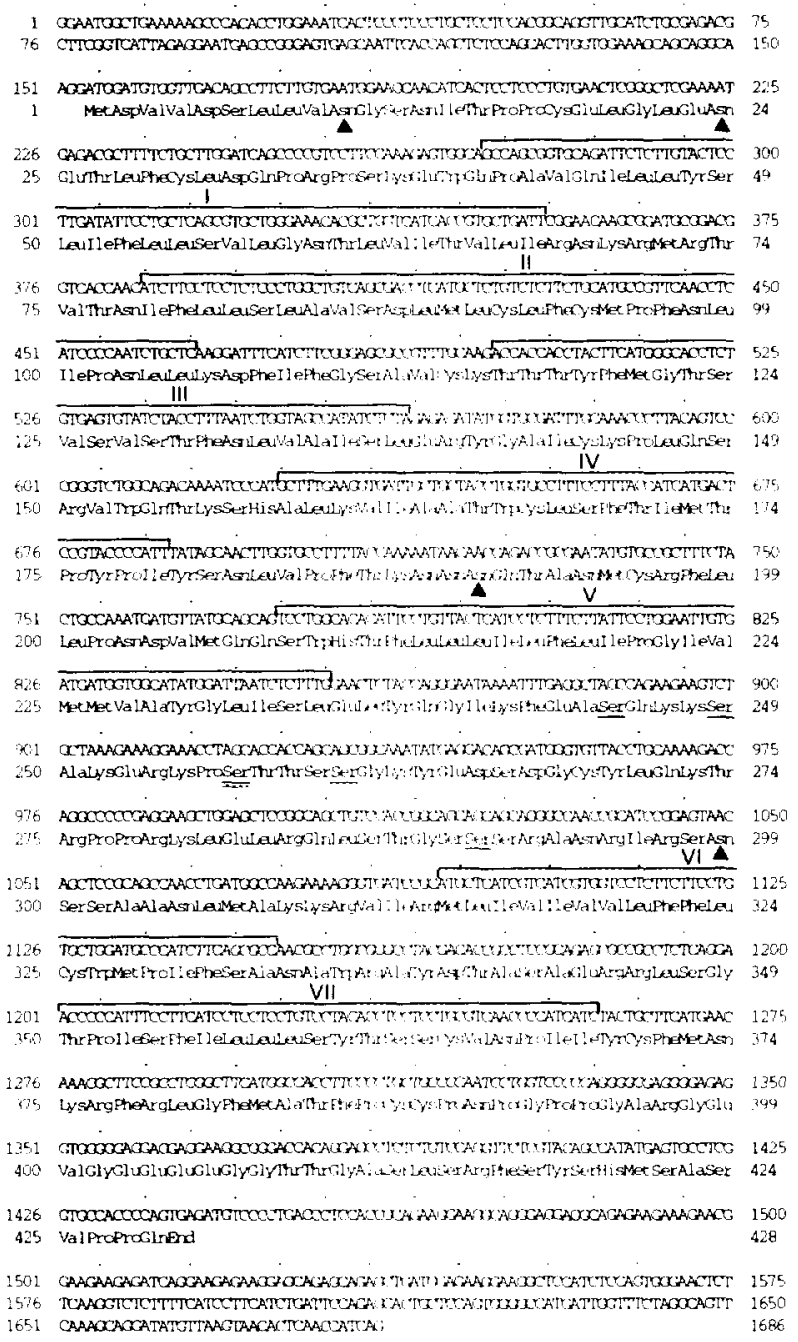

Fig. 1. Nucleotide and deduced amino acid sequences of the human gallbladder $\mathrm{CCK}_{\mathrm{A}}$ receptor CDNA clone. The solid lines labelled with Roman numerals I-VII delineate the putative transmembrane domains predicted by the Kyte-Doolittle criteria (28), and homology with the rat and guinea pig $\mathrm{CCK}_{\mathrm{A}}$ receptors. The solid triangles indicate potential sites for $\mathrm{N}$-linked glycosylation. The solid underlines indicate potential protein kinase $\mathrm{C}$ (single underline) or protein kinase A (double underline) sites for serine and threonine phosphorylation (31).

members of the G-protein-coupled superfamily of receptors (30) (Fig.1). The sequence allows for four potential N-linked glycosylation sites, two in the amino terminus, one in the second extracellular loop and one in the third intracellular loop (Fig. 1). The number of potential N-linked glycosylation sites is similar to rat (19) and guinea pig (29) $\mathrm{CCK}_{\mathrm{A}}$ receptors. There are five potential sites for protein kinase $C$ phosphorylation and one for protein kinase $A$ phosphorylation (31) all on serines in the third intracellular loop (Fig.1). There are potential $\beta$-adrenergic receptor kinase-like phosphorylation sites on threonines and serines following a series of glutamic acid residues in the cytoplasmic tail (32) (Fig.1).

A comparison of the amino acid sequence of the human $\mathrm{CCK}_{\mathrm{A}}$ receptor with rat and guinea pig $\mathrm{CCK}_{\mathrm{A}}$ receptors $(19,29)$ shows a 90 and $91 \%$ identity, respectively, with the highest degree of 


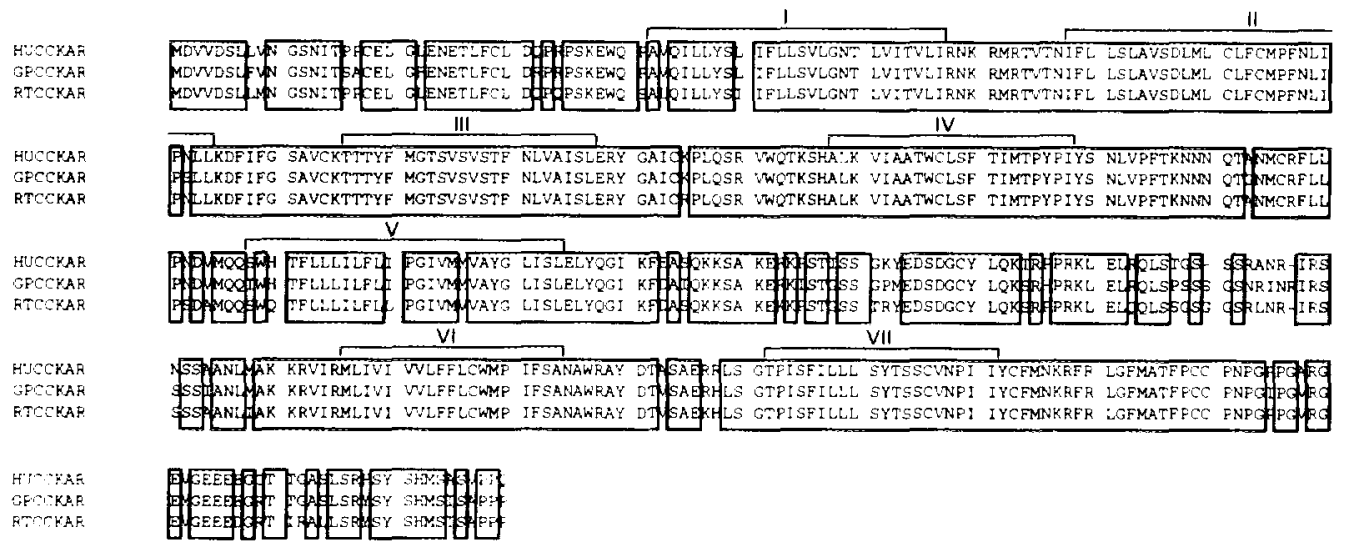

Fig. 2. Alignment of the human $\mathrm{CCK}_{\mathrm{A}}$ receptor (HUCCKAR), rat $\mathrm{CCK}_{\mathrm{A}}$ receptor (RTCCKAR) and guinea pig $\mathrm{CCK}_{\mathrm{A}} \mathrm{R}$ receptor (GPCCKAR) deduced protein sequences. Using the "Pileup" program sequence analysis package of the Genetics Computer Group (21) the human $\mathrm{CCK}_{\mathrm{A}}$ receptor was aligned for maximal homology with the rat and guinea pig $\mathrm{CCK}_{\mathrm{A}}$ receptor. Shown here using amino acid acid letter symbols is the result of this alignment with solid lines indicating putative transmembrane domains and boxed letters indicating amino acids from rat and guinea pig not conserved in the human receptor sequence.

homology in the transmembrane domains and the least degree of homology in the amino and carboxy termini and the third intracellular loop (Fig. 2). The human receptor is 1 and 2 amino acids shorter than the rat and guinea pig $\mathrm{CCK}_{\mathrm{A}}$ receptors, respectively, because of variation in the third intracellular loop (Fig 2). Similar to the rat and guinea pig $\mathrm{CCK}_{\mathrm{A}}$ receptors there are conserved cysteines in the first and second extracellular loops which may form a disulfide bridge required for stabilization of the tertiary structure as demonstrated for thodopsin (33), B-adrenergic (34), and muscarinic receptors (35) (Fig 2). A cysteine in the carboxy-terminus may be a membrane anchoring palmitoylation site similar to rhodopsin and the B-adrenergic receptors $(36,37)$ (Fig 2 ).

High stringency northern blot analysis using $2 \mu \mathrm{g}$ of human organ specific polyadenylated mRNA reveals that the $\mathrm{CCK}_{\mathrm{A}}$ receptor cDNA full-coding-region probe hybridizes to a $6 \mathrm{~Kb}$ transcript only in gallbladder as compared to the human $\mathrm{CCK}_{\mathrm{B}}$ receptor cDNA probe (using the same blot) that hybridizes to predominantly a $2.8 \mathrm{~Kb}$ transcript and to a lesser degree to a $3.3 \mathrm{~Kb}$ transcript in brain, stomach, pancreas, kidney, liver, lung and gallbladder. No hybridizing transcripts were identified in smooth muscle (data not shown). The absence of $\mathrm{CCK}_{\mathrm{A}}$ receptor hybridizing transcripts for human pancreas was surprising because rat and guinea pig pancreas contain strongly hybridizing $\mathrm{CCK}_{\mathrm{A}}$ receptor transcripts $(19,29)$ and previous in vivo human studies using the $\mathrm{CCK}_{\mathrm{A}}$ receptor specific antagonists, loxiglumide, indicate that $\mathrm{CCK}_{\mathrm{A}}$ receptors mediate pancreatic secretion (38). However, it is possible that neuronal $\mathrm{CCK}_{\mathrm{A}}$ receptors mediate pancreatic secretion through the release of acetylcholine in humans in which case the northern blot analysis would be negative or too insensitive to identify a small number of hybridizing transcripts within these neurons. The absence of hybridizing transcipts in brain and stomach is consistent with the small number of cells expressing $\mathrm{CCK}_{\mathrm{A}}$ receptors in these tissues. The $\mathrm{CCK}_{\mathrm{A}}$ receptor transcript size in humans, $6 \mathrm{~Kb}$, is considerably larger than the 2.7 and $4.4 \mathrm{~Kb}$ size found in rats and guinea pigs, respectively $(19,29)$ (Fig. 3).

To identify the human chromosomal location of the $\mathrm{CCK}_{\mathrm{A}}$ receptor, we used human $\mathrm{CCK}_{\mathrm{A}}$ receptor sequence specific primers in a PCR assay on a panel of human-hamster chromosomal hybrid DNA's and human controls. Two hybrids, \#803 and \#1006 scored positive indicating that the human 

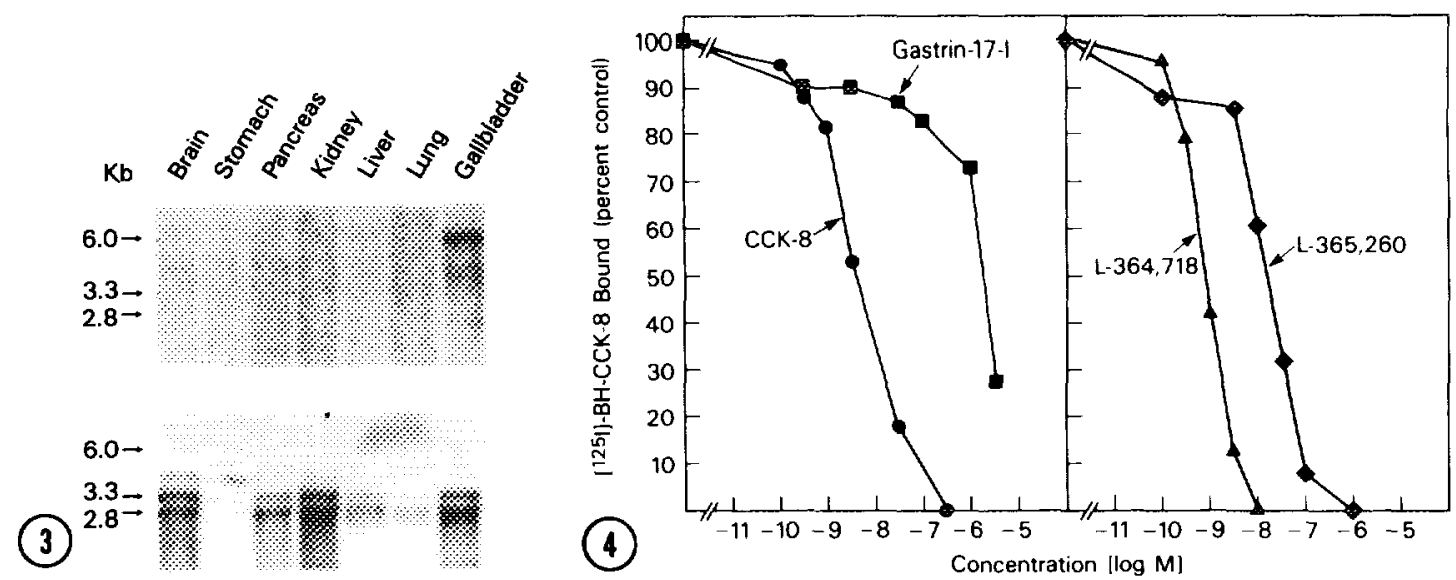

Fig. 3. Northern blot analysis of poly (A)+ RNA from the human tissues. Two micrograms of poly (A) + RNA from human brain, stomach, pancreas, kidney, liver, lung and gallbladder was separated on a $1.5 \%$ denaturing/formaldehyde agarose gel and probed under conditions of high stringency with the full coding region of the human $\mathrm{CCK}_{\mathrm{A}}$ receptor (upper) and human $\mathrm{CCK}_{\mathrm{B}}$ (26) (lower) receptor cDNA labelled with [32P] by random primer extension. The blot was exposed for 48 hours and scanned with a phosphorimager (Molecular Dynamics). The size and migration of standard RNAareindicated on the left in $\mathbf{K b}$. The human $\mathrm{CCK}_{\mathrm{A}}$ receptor $\mathrm{cDNA}$ probe hybridized to a $6.0 \mathrm{~Kb}$ transcript only in gallbladder. Using the same blot, the human $\mathrm{CCK}_{B}$ receptor hybridized predominantly to a $2.8 \mathrm{~Kb}$ transcript and to a lesser degree to a $3.3 \mathrm{~Kb}$ transcript in brain. stomach, pancreas, kidney, liver, lung and gallbladder.

Fig. 4. Ability of CCK receptor agonists and antagonists to inhibit binding of [1251]BH-CCK-8 to COS-7 cells expressing the human $\mathrm{CCK}_{\mathrm{A}}$ receptor. $\mathrm{COS}-7$ cells were transfected with the mammalian expression vector, pCDL-SR $\alpha$, containing the human $\mathrm{CCK}_{\mathrm{A}}$ receptor cDNA. Transfected COS-7 cells were incubated with either the tracer alone or with increasing concentrations of agonists CCK-8 or gastrin-17-I (left panel) or antagonists L-365,260 and L-364,718 (right panel). Data are presented as percent saturable binding (total binding in the presence of labelled hormone alone minus binding in the presence of $1 \mu \mathrm{M}$ CCK-8).

$\mathrm{CCK}_{\mathrm{A}}$ receptor resides on chromosome 4 because this is the only human chromosome retained in both hybrids \#803 and \#1006. The localization of the $\mathrm{CCK}_{\mathrm{A}}$ receptor to chromosome 4 and the previous localization of the $\mathrm{CCK}_{\mathrm{B}}$ receptor to chromosome 11 (26) suggests that these genes may be independently regulated.

To demonstrate, for the first time, the precise pharmacology of a pure human $\mathrm{CCK}_{\mathrm{A}}$ receptor, the $\mathrm{CCK}_{\mathrm{A}}$ receptor clone isolated from human gallbladder was expressed in transfected cells and ligand binding dose-inhibition studies were performed. The human $\mathrm{CCK}_{\mathrm{A}}$ receptor $\mathrm{CDNA}$ obtained from PCR cloning (1686 bp insert) was cloned into the Xba I site of the mammalian expression vector, pCDL-SR $\alpha$, and transfected into COS-7 cells using DEAE/dextran. Radioligand binding studies using [125I]-BH-CCK-8 alone or in the presence of increasing concentrations of either unlabelled CCK receptor agonists or antagonists were performed. These studies showed that [125I]BH-CCK-8 binding inhibition by CCK-8 $\left(\mathrm{IC}_{50}=3 \times 10^{-9} \mathrm{nM}\right)$ was 600 -fold more potent than gastrin-17-I $\left(\mathrm{IC}_{50}=1.8 \times 10^{-6} \mathrm{nM}\right)$ and inhibition by the $\mathrm{CCK}_{\mathrm{A}}$ receptor antagonist, L-364,718 $\left(\mathrm{IC}_{50}\right.$ $=0.8 \times 10^{-9} \mathrm{nM}$ ) was 25 -fold more potent than the $\mathrm{CCK}_{B}$ receptor specific antagonist L-365,260 $\left(\mathrm{IC}_{50}=2 \times 10^{-8} \mathrm{nM}\right)$ (Fig. 4). These findings are characteristic of a $\mathrm{CCK}_{\mathrm{A}}$ receptor subtype pharmacology and are similar to that reported previously for $\mathrm{CCK}_{\mathrm{A}}$ receptors on CHP 212 human neuroblastoma cells (39) as well as for native (2) and transfected rat (19) and guinea pig (29) $\mathrm{CCK}_{\mathrm{A}}$ receptors. 

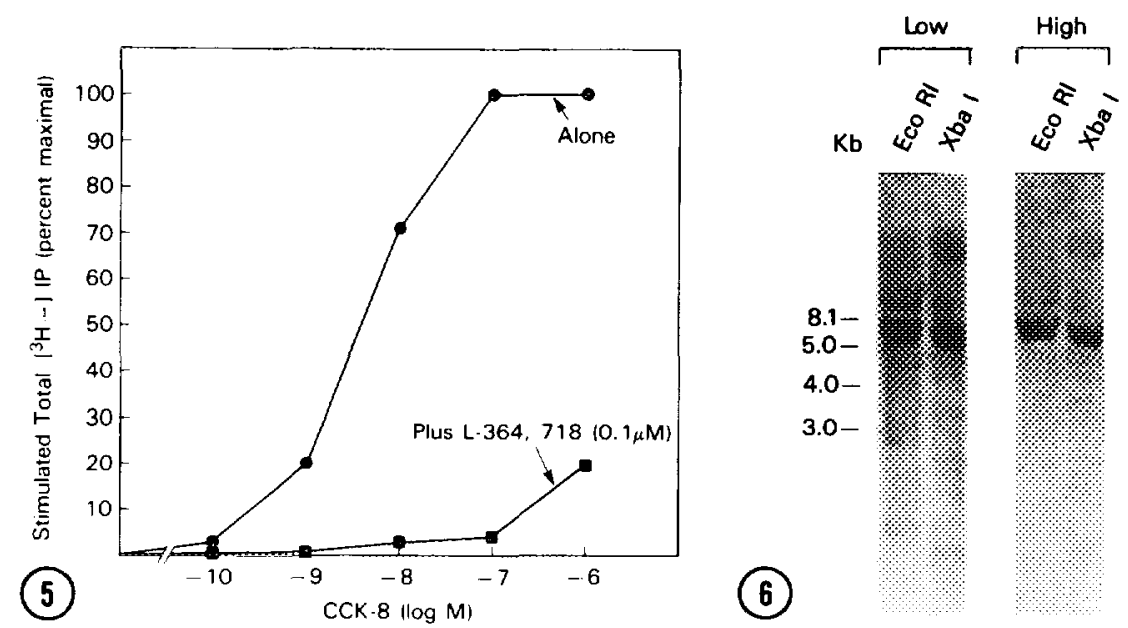

Fig. 5. Ability of CCK-8 alone or CCK-8 plus L-364,718 to stimulate total [ $3 \mathrm{H}$ ]inositol phosphate generation in COS-7 cells transfected with the human $\mathrm{CCK}_{\mathrm{A}}$ receptor. Data are expressed as the percentage of maximal increase obtained using $1 \mu \mathrm{M}$ CCK-8. CCK-8 $(1 \mu \mathrm{M})$ increased [3H]inositol phosphates from a basal level of $3821+/-393 \mathrm{dpm}$ to $28617+/-762 \mathrm{dpm}$ (mean $+/$ - SEM). Separation of total [3H]inositol phosphates was performed as detailed in Materials and Methods.

Fig. 6. Human genomic Southern blot analysis. Ten $\mu g$ of human genomic DNA was digested with either Eco RI or Xba I, blotted onto Nytran and hybridized with the radiolabelled human CCK $_{A}$ receptor cDNA probe under conditions described in Materials and Methods. The blot was exposed for 48 hours and processed using a phosphorimager following each of the low and high stringency washes. The size and migration of standard DNA are indicated on the left in $\mathrm{Kb}$.

To determine whether the $\mathrm{CCK}_{\mathrm{A}}$ receptor clone isolated from human gallbladder encodes a functional $\mathrm{CCK}_{\mathrm{A}}$ receptor capable of activating phospholipase $\mathrm{C}$, we measured the increase of phosphoinositides stimulated by CCK- 8 in COS- 7 cells expressing the transfected receptor. CCK-8 casused a dose dependent increase in total inositol phosphates with a detectable increase at $0.1 \mathrm{nM}$, a half maximal increase at $3.0 \mathrm{nM}$ and a maximal increase at $100 \mathrm{nM}$. This response was nearly completely inhibited by the $\mathrm{CCK}_{\mathrm{A}}$ receptor specific antagonist, $\mathrm{L}-364,718$, at $0.1 \mu \mathrm{M}$ (Fig. 5). Thse results are in close agreement with previous studies of $\mathrm{CCK}_{\mathrm{A}}$ receptors on the human neuroblastoma cell line, CHP212 (39).

Several pharmacological $(40,41,42)$ and biochemical studies $(13,18,43)$ in aniamals suggest that there may be multiple subtypes of $\mathrm{CCK}_{\mathrm{A}}$ receptors. To discover other potential $\mathrm{CCK}_{\mathrm{A}}$ receptor subtypes, we performed Southern blot hybridization of human DNA using a radiolabeled full length coding sequence probe of the human $\mathrm{CCK}_{\mathrm{A}}$ receptor cDNA under conditions of low and then high stringency. DNA cut either with Eco RI or Xba I contained a single hybridizing restriction fragment of $\approx 5.5$ and $5.0 \mathrm{~Kb}$, respectively, under both low and high stringency conditions. These results, taken together with the the identification of single hybrizing cDNA on low stringency genomic library hybridization screening and a single hybridizing transcript on low and high stringency northern hybridization suggests that there is only a single $\mathrm{CCK}_{\mathrm{A}}$ receptor subtype (Fig. 6).

In summary, the results presented here describe for the first time the cloning of the human $\mathrm{CCK}_{\mathrm{A}}$ receptor. The expression of the recombinant receptor in transfected cells faithfully reproduces the expected subtype pharmacology and second messenger coupling leading to phosphinositide hydrolysis reported for native human $\mathrm{CCK}_{\mathrm{A}}$ receptors. The availability of the recombinant human $\mathrm{CCK}_{\mathrm{A}}$ receptor will enhance our ability to develop specific agonists and antagonists and study the 
localization and structure-function relationships for gastrointestinal and central nervous system $\mathrm{CCK}_{\mathrm{A}}$ receptors. Ultimately, this should hasten the understanding and therapy of gastrointestinal and neuropsychiatric disorders.

\section{REFERENCES}

1. Hill, D.R., Campbell, N.J., Shaw, T.M., and Woodruff, G.N. (1987) J. Neurosci. 7, 2967-2976.

2. Jensen, R.T., Wank, S.A., Rowley, W.H., Sato, S., and Gardner, J.D. (1989) Trends Pharmacol. Sci. $10,418-423$.

3. Chang, R.S.L., and Lotti, V.J. (1986) Proc. Natl. Acad. Sci. 83, 4923-4926.

4. Merrit, J.E., Taylor, C.W., Rubin, R.P., and Putney, J.W. (1986) Biochem. J. 236, 337-343.

5. Innis, R.B. \& Snyder, S.H. (1980) Proc. Natl. Acad. Sci. USA 77, 6917-6921.

6. Chew, C.S. \& Brown, M.R. (1986) Biochim. Biophys. Acta 888, 116-125.

7. Liddle, R.A., et al. (1989) Am. Soc. Clin. Invest. 84, 1220-1225.

8. Schmidt, W.E.,et al. (1991) Am. J. Physiol. 260. G197-G206.

9. Kellow, J.E., et al. (1987) Am. J. Physiol. 253, G650-G655.

10. Rushakoff, R.A., et al. (1993) J. Clin. Endocrinol. Metab. 76, 489-493.

11. Edwards, B.F., Redding, T.F., and Schally, A.V. (1989) Int. J. Pancreatol. 5, 191-201.

12. Miller, L.J. (1984) Am. J. Physiol. 247, G402-G410.

13. Pearson, R.K., Hadac, .M., and Miller, L.J. (1989) Am. J. Physiol. 256, G1005-1010.

14. Smith, J.P., Solomon, T.E., Bagheri, S. and Kramer, S. (1990) Dig. Dis. and Sci. 35, 1377-1384.

15. Crawley, J.N. (1991) Trends Pharmacol. Sci. 12, 232-236.

16. Moran, T.H., Robinson, P.H., Goldrich, M.S., and McHugh, P.R. (1975) Brain Res. 362, 986-89.

17. Hornung, J.P., Tribolet, N.D. and Tork, I. (1992) Scand. J. Gastroenterology. 27, 993-998.

18. Schjoldager, B., Molero, X. and Miller, L.J. (1989) Gastroenterology. 96, 1119-1125.

19. Wank, S.A., Harkins, R., Jensen, R.T., Shapira, H., de Weerth, A. \& Slattery, T. (1992) Proc. Natl. Acad. Sci. USA 89, 3125-3129.

20. Han, J.H., Stratowa, C., and Rutter, W.J. (1987) Biochemistry. 26, 1617-25.

21. Devereaux, J., Haebrli, P., and Smithies, O. (1984) Nucleic Acids Res. 12, 387-395.

22. Davis, L., Dibner, M. and Battey, J .F., (1986) Basic Methods in Molecular Biology Elsevier, New York, 1-388.

23. Takebe, Y., et. al. (1988) Mol. Cell. Biol. 8, 466-472.23. Cullen, B.R. (1987) Methods Enzymol. $152,684-704$.

24. Cullen, B.R. (1987) Methods Enzymol. 152, 684-704.

25. Benya, R.V., et al (1992) Mol. Pharmacol. 42, 1058-1068.

26. Pisegna, J.R., de Weenh, A., Huppi, K. and Wank, S.A. (1992) Biochem. Biophys. Res. Comm. 189, 296-303.

27. Schjoldager, B., Molero, X. and Miller, L.J. (1990) Regul. Pept. 28, 265-272.

28. Kyte, J., and Doolittle, R.R. (1982) J. Mol. Biol. 157, 105-132.

29. de Weerth, A., Pisegna, J.R. and Wank, S.A. (1993) Am. J. Physiol. 265, (in press).

30. Dohlman, H. G., Caron, M. G. and Lefkowitz, R. J. (1987) Biochemistry 26, 2657-2663.

31. Kennelly, P.J., and Krebs, E.G. (1991) J. Biol. Chem. 15555-15558.

32. Onorato, J.J., et al. (1991) Biochemistry 30, 5118-5125.

33. Karnik, S.S., et. al. (1988) Proc. Natl. Acad. Sci. USA. 85, 8459-8463.

34. Dixon, R.A., et. al. (1987) EMBO. J. 6, 3269-3275.

35. Hulme, E.C., Birdsall, N.J., and Buckley, N.J. (1990) Annu. Rev. Pharmacol.

36. O'Dowd, B., et. al. (1989) J. Biol. Chem. 264, 7564-7569.

37. Ovchinikov, Y.A., Abdulaev, N.G., and Bogachuk, A.S.(1988) FEBS Lett. 230, 1-5.

38. Fried, M., et al. (1991) Gastroenterology. 101, 503-511,

39. Barrett, R.W., Steffey, M.E. and Wolfram, A.W. (1989) Mol. Pharmacol. 35, 394-400.

40. Jensen, R.T., et al. (1986) Am. J. Physiol. 251, G839-G846.

41. Macovec, F., et al. (1986) Eur. J. Med. Chem. 21, 9-20.

42. Yaniahara, C., et al 1985) Biomed. Res. 6, 111-115.

43. Schjoldager, B., et al. (1988) Am. J. Physiol. 254, G294-G299. 